\title{
Strategi Pembelajaran Tanpa Kekerasan
}

\author{
Muhammad Idrus*
}

\begin{abstract}
This paper will discuss learning strategy models which put student as subject of learning. Teacher is expected to take an advantage in using those models to reduce violence in education circumstance. As found in researches and mass media, violence in education circumstances, which is performed by teachers or students, still become high concerns among parents, teachers, and students themselves. One such thing that may cause this violence is learning and teaching approach or strategy by which teachers use. Changing learning and teaching strategy to be more effective and fun will probably reduce those sort of violence in education circumstances, like in schools or universities. The individual character of teachers and students are also discussed in this paper to find other factors of violence in education.
\end{abstract}

Keywords: violence in education, learning strategy, student centered learning.

* Penulis adalah dosen tetap Program Studi Pendidikan Agama Islam FIAI UII Yogyakarta

\section{A. Pendahuluan}

Anak didik merupakan bagian yang paling penting dalam proses pendidikan. Hal tersebut mengingat fokus utama proses pendidikan adalah pembentukan anak didik menjadi manusia-manusia baru, menjadikannya menyadari tentang potensipotensi kemanusian yang dimiliki, dan menggunakan potensinya itu sesuai dengan norma budaya dan agama yang dianutnya (Idrus, 1997b). Lazimnya, proses pendidikan dilakukan secara manusiawi sesuai dengan harkat dan martabat kemanusian. Hanya saja pada kenyataannya tidak selamanya dan tidak semua proses pendidikan berjalan sebagaimana yang diharapkan.

Setidaknya, publik seringkali dihadapkan pada kenyataan adanya berita tentang tindak kekerasan yang terjadi di lingkungan sekolah. Sekolah yang seharusnya mengajarkan masalah moral, yang seharusnya menjadi garda terdepan dalam mengawal peradaban, justru tercemar oleh perilaku siswa dan guru yang melakukan tindak kekerasan. Tindakan kekerasan tersebut tentu akan menghancurkan pilarpilar peradaban.

Kekerasan (dalam pendidikan dikenal dengan istilah bullying) dapat diartikan sebagai suatu tindakan yang tidak menyenangkan atau merugikan orang lain, baik secara fisik maupun psikis. Kekerasan atau bullying dibedakan menjadi kekerasan fisik dan psikis. Kekerasan fisik berupa tindakan pemukulan (menggunakan tangan atau alat), penamparan, dan tendangan. Dampaknya, tindakan tersebut dapat menimbulkan bekas luka atau memar pada tubuh, bahkan dalam kasus tertentu dapat mengakibatkan kecacatan permanen yang harus ditanggung seumur hidup oleh si korban.

Kekerasan psikis dapat berwujud tindakan mengejek atau menghina, mengintimidasi, menunjukkan sikap atau ekspresi tidak senang, dan tindakan atau ucapan yang melukai perasaan orang lain. Dampak kekerasan secara psikis dapat menimbulkan perasaan tidak nyaman, takut, tegang, bahkan dapat menimbulkan efek traumatis yang cukup lama. Dampak lain yang timbul adalah menjadi pendiam (penyendiri), minder dan canggung dalam bergaul, tidak mau sekolah, stres, sehingga tidak konsentrasi dalam belajar, dan dalam beberapa kasus yang lebih parah dapat mengakibatkan bunuh diri.

Survei yang dilakukan oleh LSM Plan Indonesia dan Yayasan Sejiwa pada 2008 di tiga kota besar, yakni Jakarta, Surabaya, dan Yogyakarta menemukan, sekitar 67 persen dari 1.500 pelajar pernah mengalami bullying di sekolahnya. Pelakunya mulai dari teman, kakak kelas, adik kelas, guru, hingga 
preman yang ada di sekitar sekolah. Adapun bentukbentuk bullying yang ditemukan di sekolah mulai dari dipukul, ditonjok, ditampar, dihina, lirikan mengejek, julukan negatif, hingga pelecehan seksual. Sedangkan lokasi kejadian mulai dari toilet, kantin, halaman, pintu gerbang sekolah, bahkan di dalam ruang kelas (http://keyanaku.blogspot.com/2009/02/ belajar-di-sekolah-tanpa-rasa-takut.html).

Lantas, apa akibatnya? Sekolah tampaknya bukan lagi tempat yang menyenangkan bagi siswa, tapi justru menjadi tempat yang menakutkan dan membuat trauma. Kejadian demi kejadian terus berulang. Setiap tindak kekerasan di lingkungan lembaga pendidikan sepertinya tidak pernah hilang. Dan korban yang mengalami stres, trauma, ketakutan, luka fisik, cacat permanen, bahkan meninggal dunia sepertinya tidak menjadi bahan perenungan.

Publik dapat melihat di media massa, betapa ada oknum guru yang melakukan kekerasan terhadap para siswanya. Seharusnya, apapun alasannya, tidak layak bagi seorang guru untuk melakukan tindak kekerasan terhadap siswanya. Perlakuan kasar dan pelecehan terhadap siswa hanya akan menjadikan siswa kehilangan harga dirinya. Pada ujungnya, jika siswa tersebut berani untuk menampilkan emosinya, maka yang muncul adalah dendam terhadap guru yang melakukan kekerasan.

Contoh lain kekerasan yang timbul di sekolah adalah yang terjadi dalam proses belajar-mengajar. Dengan dalih untuk menegakkan disiplin, terkadang guru memberikan hukuman yang sama sekali tidak mendidik. Tidak jarang guru memberikan hukuman berupa aktivitas fisik semisal berlari, push up, menulis kata tertentu sebanyak-banyaknya, atau bahkan melakukan hukuman dengan menjewer, bahkan ada juga yang melakukan pemukulan.

Jika sudah demikian, maka dapat dipastikan proses pembelajaran akan berlangsung dengan tidak menyenangkan. Siswa belajar dalam kondisi tertekan dan jika hal itu terjadi, maka dapat dipastikan siswa sulit untuk dapat mencerna materi pelajaran yang diajarkan guru.

\section{B. Strategi Belajar yang Menyenangkan}

Model pembelajaran dengan memposisikan siswa sebagai objek sudah selayaknya diubah. Paradigma ini tidak lagi menghargai potensi yang dimiliki siswa. Untuk itu, sudah selayaknya guru dan pendidik merancang sebuah desain pembelajaran yang menyenangkan, yang merangsang siswa untuk belajar dan terlibat dalam situasi belajar.

Jika semula semua terpusat pada pendidik, maka saat ini harus diarahkan pada siswa (student centered). Perubahan paradigma ini harus pula disertai dengan perubahan model ataupun metode belajar yang kita lakukan, dan itu dengan sendirinya mengharuskan pendidik untuk kembali menekuni metode pembelajaran yang sesuai dengan tuntutan zaman.

Banyak model pembelajaran yang dapat meniadakan tindak kekerasan di kelas. Misalnya model active learning yang dikembangkan oleh Melvin L. Silberman (2006). Active learning menyajikan 101 strategi pembelajaran aktif yang dapat diterapkan hampir untuk semua materi. Dalam active learning diasumsikan bahwa belajar membutuhkan keterlibatan mental dan tindakan sekaligus, sehingga dalam proses pembelajaran siswa melakukan sebagian besar pekerjaan belajar dengan cara mempelajari gagasan-gagasan, memecahkan berbagai masalah dan menerapkan apa yang mereka pelajari.

Model lain adalah accelerated learning (pembelajaran yang dipercepat) yang diajukan oleh Dave Meier (2002). Konsep dasar dari pembelajaran ini adalah bahwa pembelajaran itu berlangsung secara cepat, menyenangkan, dan memuaskan. Meier (2002) menyarankan dalam mengelola kelas guru agar menggunakan pendekatan Somatic, Auditory, Visual, dan Intellectual (SAVI). Somatic dimaksudkan sebagai learning by moving and doing (belajar dengan bergerak dan berbuat). Auditory adalah learning by talking and hearing (belajar dengan berbicara dan mendengarkan). Visual diartikan learning by observing and picturing (belajar dengan mengamati dan menggambarkan). Intellectual maksudnya adalah learning by problem solving and reflecting (belajar dengan pemecahan masalah dan melakukan refleksi).

Model ketiga yang dapat dipakai adalah model belajar dengan gaya "quantum learning". Istilah quantum diambil dari terminologi dunia fisika, yang kurang lebih memiliki makna etimologi loncatan, makna lain dari istilah ini adalah mengacu pada teori fisika quantum yang berbunyi massa kali kecepatan cahaya kuadrat sama dengan energi. Rahmat (1997) mengungkap bahwa pengadopsian istilah quantum 
dalam quantum learning untuk menunjukkan bahwa manusia memiliki potensi untuk berkembang (potential for growth).

Salah satu yang ditekankan dalam paradigma quantum learning adalah penciptaan lingkungan belajar yang dapat membuat siswa senang dalam belajar. Lingkungan yang dimaksud dalam tulisan ini adalah lingkungan fisik yang terdiri dari penataan ruang, kursi, meja, papan dan alat bantu lain yang berada di kelas, ataupun yang berada di luar kelas, serta lingkungan emosional berupa interaksi antara pendidik-siswa, maupun antara siswa-siswa.

Dalam tulisannya sebagaimana dikutip Rahmat (1999), De Porter mengungkap bahwa dengan mengendalikan lingkungan, berarti kita telah melakukan langkah efektif pertama untuk mengendalikan seluruh pengalaman belajar yang kita miliki, dan salah satu keberhasilan program quantum learning adalah dapat terciptanya lingkungan optimal baik secara fisik dan emosional. Dari hasil penelitiannya, Idrus (1997a) menemukan bahwa lingkungan belajar berpengaruh pada proses belajar mengajar.

Dalam keseharian kita melakukan proses interaksi belajar mengajar, kita melupakan bahwa lingkungan yang kita tempati adalah lingkungan yang telah ada wujud fisiknya seperti itu dari tahun ke tahun, dan berlangsung sekian tahun. Kita tidak sempat untuk memperhatikan kondisi lingkungan kita mengajar, dan kita hanya dapat marah saat menemui ruangan tidak seperti yang kita harapkan. Lantas apa upaya untuk mendesain ruang itu? Hampir tidak ada.

Penulis tertarik dengan model salah satu sekolah di Jepang, penulis lupa sekolah apa, penulis hanya ingat saat itu pernah ditayangkan pada berita di salah satu TV swasta. Untuk mengembangkan kreativitas siswanya, sekolah mempersilakan siswa menulis ataupun melukis dinding-dinding yang ada di sekolah. Ternyata hasilnya sangat menakjubkan, siswa-siswa bergairah untuk belajar, dan mereka merasa senang sebab karyanya akan terus dipampang selama 1 (satu) tahun ajaran. Saat pergantian tahun ajaran, dinding sekolah akan kembali bersih lagi, dan siap untuk dilukis kembali oleh anak-anak.

Kesan kita saat menyaksikan tayangan itu adalah mahal! dan itu juga kesan pertama penulis. Ini menjadi hal yang dilematis di negara seperti Indonesia saat ini. Dilema antara untuk memajukan pendidikan anak-anak bangsa dengan besar biaya yang harus ditanggung, dan kita belum siap untuk menerima kenyataan bahwa proses pendidikan yang baik itu memerlukan anggaran yang banyak.

Meski tidak harus persis sama seperti sekolah di Jepang itu, tampaknya kita juga dapat mendesain ruang kelas kita menjadi lebih semarak tanpa harus mengeluarkan biaya yang besar. Setidaknya saat ini mulailah meninggalkan anggapan bahwa kelas yang baik adalah kelas yang dicat putih, tawarkanlah pada penghuni kelas untuk memilih warna cat dan biarkan mereka mengecatnya secara bersama-sama. Barangkali ini justru akan menjadikan identitas kelas mereka, dan perlu dipahami bersama masamasa sekolah SMU ke bawah adalah masa-masa kebanggaan akan identitas diri. Jika ide ini tewujud, maka sekolah akan memiliki kelas dengan variasi warna yang berbeda antar kelas, dan itu juga akan menunjukkan arah identitas mereka masingmasing.

Kelas kita adalah kelas dengan meja dan kursi yang tidak nyaman. Bahkan untuk tingkat pendidikan tinggi sekalipun masih dijumpai model kursi yang tidak memberikan kenyamanan dalam belajar. Ada beberapa sekolah yang masih dijumpai memiliki meja dan kursinya menjadi satu, sulit untuk digeser. Untuk kenyamanan belajar, idealnya kursi sudah langsung dengan tatakan untuk menulis yang didesain individual, sehingga siswa dapat menggeser kursinya kemana dia suka. Lazimnya model ini kurang disenangi para pendidik kita, sebab asumsi yang dibangun adalah belajar harus dengan teratur kursinya, bukan teratur berpikirnya.

Kondisi kelas yang ideal adalah kelas yang memberikan kenyamanan dalam belajar, salah satunya dapat tercapai dengan cara memberi keleluasaan kepada anak didik untuk memilih cara duduk yang disenanginya. Biarkan siswa memilih di mana dia akan menempatkan kursinya. Untuk desain yang terbaik memang diharapkan posisi guru/dosen/pendidik berada di tengah-tengah siswa, sehingga seluruh siswa dapat melihat aktivitas guru/ dosen/pendidik dengan sempurna, kondisi tersebut dapat diperoleh jika desain tempat duduk siswa ditempatkan pada posisi melingkar, atau membentuk huruf U.

Saran De Porter \& Hernacki dalam menciptakan ruang belajar yang nyaman malah ditambah dengan diperdengarkannya musik. Beberapa hasil penelitian 
menunjukkan adanya korelasi antara musik dengan kemampuan akademik (Pekerti, 2000). Terkait dengan musik ini, ada sebuah penelitian yang menemukan bahwa jumlah produk telur dari ayamayam petelur meningkat setelah diperdengarkan musik pada waktu-waktu tertentu. Meski manusia jelas tidak sama dengan ayam, namun berdasarkan logika penelitian ini, jika musik memmberi efek yang positif pada ayam, tentu musik akan lebih memberikan efek positif yang lebih kuat pada manusia. Dan bagi De Porter, dkk. (2000) musik dapat membantu pelajar bekerja lebih baik, dan mengingat lebih banyak.

Jika mengingat saat belajar di TK, betapa kita serasa mudah mengingat sesuatu saat materi itu dinyanyikan, dan tampaknya model pendekatan ini menjadi model ideal saat di TK dahulu. Namun saat ini, ruang belajar kita adalah ruang belajar yang sunyi senyap, kelas dianggap baik jika siswanya diam, tidak ada suara. Guru/dosen merasa puas tatkala menyaksikan siswa/mahasiswanya belajar dengan tanpa suara. Hingga terkadang karena inginnya menciptakan suasana tenang di kelas, secara tidak sengaja kita-kita sebagai pendidik mengabaikan bahwa mereka punya potensi yang tersimpan dalam banyak pertanyaan yang tak sempat terungkapkan.

Kelas ramai dalam suasana diskusi membicarakan tema materi pelajaran terkadang tidak siap dilakukan oleh guru/dosen, karena pada sisi ini guru/dosen harus siap-siap selalu meng-up to date pengetahuan yang dimilikinya. Pada sisi ini, kesibukan guru/dosen menjadi salah satu hambatan yang tak terelakkan. Pemilihan jenis musik, tampaknya harus secara arif dilakukan, setidaknya jika tidak menyenangi musik klasik, maka lagu-lagu instrumental menjadi pilihan tepat seandainya ingin memperdengarkan musik di ruang-ruang kelas.

Adanya iringan musik di saat belajar, dapat mempengaruhi kondisi fisiologis siswa/mahasiswa. Dengan begitu saat menghadapi pekerjaan berat dengan tekanan mental, dan tekanan darah yang naik, serta denyut jantung yang mengencang, secara berangsur-angsur terjadi relaksasi yang tanpa disadari. Bagi De Porter \& Hernicki (1999) relaksasi yang diiringi musik membuat pikiran selalu siap dan mampu berkonsentrasi. Inilah eksperimen, sekolah dengan iringan musik belum pernah ada, saat ini beberapa sekolah menggunakan irama musik baru untuk saat pergantian jam, ataupun saat istirahat, selebihnya berlalu dengan ketenangan.
Selanjutnya dalam upaya mendesain lingkungan yang nyaman adalah adanya pengingat visual sebagai penggugah motivasi belajar siswa. Slogan "katakanlah dengan bunga" barangkali merepresentasikan ungkapan ini. Pengingat visual, seperti gambar, poster lebih berarti dari seribu kata (De Porter \& Hernicki, 1999). Beberapa sekolah telah mencoba memampang hasil karya dan prestasiprestasi yang diraih siswa-siswanya.

Biasanya, pelbagai tanda prestasi itu hanya disimpan di pojok sudut ruang kepala sekolah, atau di ruang TU. Mengapa tidak di koridor, di sepanjang jalan menuju kelas-kelas? Jika ada penghargaan atas nama seorang siswa tertentu, mengapa sekolah tidak mencoba mengcopy-nya dan menempel di dinding yang dapat terlihat semua siswa?

Dari sisi psikologis, setiap individu ingin dirinya dihargai, dan itu merupakan wujud dari kebutuhan aktualisasi dirinya. Dengan memajang sertifikat atas nama seorang siswa, maka dengan sendirinya sekolah mengakui eksistensi siswa yang bersangkutan, dan menaikkan harga diri siswa. Selain itu, metode ini akan menjadi trigger (pemicu) bagi siswa-siswa lainnya untuk berprestasi, sebab pada dasarnya seluruh siswa ingin dirinya mendapat kesempatan namanya terpampang di sekolah.

Terkait dengan pengingat visual adalah alat-alat peraga saat guru/dosen menjelaskan materi tertentu di kelas. Diakui kondisi ekonomi yang terpuruk ini terkadang menjadikan kita kesulitan untuk membeli ataupun mengadakan alat peraga. Namun jangan dilupakan juga, bahwa bapak/ibu guru/dosen sendiri adalah media penyampai yang terbaik. Bapak/ibu guru/dosen berfungsi sebagai human media. Ini yang kerap dilupakan, bahwa diri guru atau pendidik adalah media terbaik untuk menyampaikan materi yang sedang kita bawakan. Untuk menjadi human media yang baik, salah satunya adalah dengan tidak pelit menggunakan bahasa-bahasa non-verbal.

Selama ini kita telah optimal menggunakan bahasa verbal, pujian ataupun dukungan terhadap siswa telah kita lakukan. Namun penggunaan bahasabahasa non-verbal terkadang tidak berani secara optimal kita lakukan. Jika siswa kita menjawab pertanyaan yang diajukan secara baik, selain dengan ungkapan verbal dapat juga kita acungkan ibu jari kita sebagai tanda pujian, dan ini mungkin menjadikan siswa lebih mantap. Mimik muka saat menerima pertanyaan, gerak tangan, bola mata, 
bibir saat menjelaskan materi sebenarnya menjadi dukungan yang akurat dalam menjelaskan materi yang sedang kita ajarkan. Beberapa keterampilan bahasa non-verbal tampaknya perlu dilatih di depan kaca, agar saat tampil di kelas ekspresi itu sudah tampak wajar dan menyenangkan siswa.

Lingkungan lain yang harus didesain adalah lingkungan emosional (psikis). De Porter \& Hernicki (1999) menjelaskan yang termasuk dalam lingkungan ini adalah hubungan antara pengajar dengan murid dan antara murid dengan murid lainnya. Bagi penulis, bukan hanya interaksi antara guru-murid, murid-murid, namun juga interaksi antara seluruh komponen yang ada di sekolah, mulai dari satpam (penjaga sekolah), tukang kebun, pegawai administratif, pengajar, murid dan juga pimpinan sekolah harus dilakukan secara humanis.

Saat SMU dahulu, betapa penulis merasa tidak nyaman jika bertemu dengan guru tertentu. Mengapa? Menurut seluruh siswa - termasuk penulis - guru tersebut tidak ramah, tidak pernah membuat kami merasa nyaman - atau karena fungsinya sebagai wakil kepala sekolah kesiswaan yang harus selalu melihat siswanya rapih, tidak gondrong, disiplin, $\mathrm{dsb}$. Sebaliknya kami juga menyenangi guru tertentu, karena meski dia memarahi kami, tidak pernah menjatuhkan harga diri kami di mata teman-teman.

Prototipe guru-guru kita dahulu adalah prototipe "penjajah", yang selalu memaksakan keinginannya pada siswa tanpa dialog. Tampaknya sudah saatnya kita tinggalkan pola lama kita, dan beralih pada model guru/dosen yang demokratis, dengan saling menghormati antara guru/dosen-siswa/mahasiswa secara egaliter. Meski untuk hal ini, siswa/ mahasiswa juga perlu belajar, bagaimana dia harus bersikap pada orang lain. Model pembelajaran kita hendaknya diarahkan pada proses penyadaran yang membawa kesadaran emosional siswa/mahasiswa ke arah yang baik.

\section{Penutup}

Jika saat siswa/mahasiswa masuk pintu gerbang, satpam memberi senyum, tukang kebun juga bekerja dengan senyum, pegawai administratif juga bersikap ramah, sampai di kelas guru/dosen datang dengan "sumringah" wajah berseri-seri, maka tampaknya rasa afeksi siswa/mahasiswa terobati. Tidak ada ketegangan dalam belajar, dan ini menjadikan lebih mudah untuk mencerna ilmu- ilmu yang akan diajarkan kepada mereka. Bukankah senyum itu ibadah? Jika ya, mengapa kita pelit untuk memberi senyum kepada siswa kita. Mungkin dengan senyum yang kita berikan akan menambah kenyamanan mereka dalam belajar. Siapa tahu?

\section{Daftar Pustaka}

De Porter, B. \& Hernacki, M. 1999. Quantum Learning: Membiasakan Belajar Nyaman dan Menyenangkan. Bandung: Kaifa.

DePorter, et. al. 2000. Quantum Teaching: Mempraktikkan Quantum Learning di Ruangruang Kelas. Bandung: Kaifa.

Idrus, Muhammad. 1997a. Otonomi Moral Keagamaan Mahasiswa. Tesis pada Fakultas Pasca sarjana UNY. Tidak diterbitkan

. 1997b. Karakteristik dan Dimensi

Moral Anak Didik dalam Pendidikan. Dalam Pendidikan Islam dalam Peradaban Industrial. Muslih Usa \& Aden Wijdan SZ (Penyunting). Yogyakarta: Aditya Media.

Meier, D. 2002. The Accelerated Learning Handbook: Panduan Kreatif dan Efektif Merancang Program Pendidikan dan Latihan. Bandung: Kaifa.

Pekerti, W. 2000. Pengaruh Pembelajaran Terpadu Matematika dan Musik Terhadap Hasil Belajar Matematika Murid Kelas Satu Sekolah Dasar. Jurnal Pendidikan dan Kebudayaan Th Ke-5 No. 022, Maret 2000.

Rahmat, J. 1997. Catatan Kang Jalal: Visi Media, Politik dan Pendidikan. Bandung: PT. Remaja Rosda Karya.

1999. Quantum Learning: Sebuah Pengantar. Jurnal Gema Edisi 1/Agustus 1999.

Silberman, M. 2006. Active Learning: 101 Cara Belajar Siswa Aktif. Bandung: Nusamedia \& Nuansa. 